\title{
Attitudes and acceptability of organ and tissue donation registration in the emergency department: A national survey of emergency nurses
}

By Michael Hickey, MD, MSc, Carly Hickey, MN, Michael Hartwick, MD, MEd, Lauralyn Mclntyre, MD, MSc, Monica Taljaard, PhD, Krishan Yadav, MD, MSc, Aimee Sarti, MD, MMEd, Jeffrey J. Perry, MD, MSc

\begin{abstract}
Introduction: Worldwide, there is a shortage of organs for transplantation. The number of people listed on organ donation registries can possibly be increased by promoting organ donation registration in emergency departments.
\end{abstract}

Methods: We administered a national survey to assess emergency nurses' attitudes and feelings on offering patients' information on registering to become an organ donor in the emergency department, as well as an immediate opportunity to register.

Results: We received 130 (10.2\%) responses. Of these, $61.5 \%$ of nurses feel that the emergency department is an acceptable location to promote organ donation registration. Additionally, 58.4\% feel that the emergency department is an appropriate setting to offer patients and visitors an immediate opportunity to register as an organ and tissue donor while they await medical care. We identified several facilitators and barriers to a potential intervention to promote organ donation registration in the emergency department, such as public importance of increasing donation rates, the recognition of patients' willingness to help others, and strong institutional donation culture. Some barriers were also identified, such as time constraints and departmental efficiency and flow. We also found that $80 \%$ of nurses report to be personally registered as organ donors.
Conclusions: This study reveals that Canadian emergency nurses are very engaged and supportive of organ donation and the majority feel that the ED is an appropriate venue to promote organ donation. However, the specific mechanism by which patients are approached by emergency department staff regarding organ donation registration remains unclear.

\section{Introduction}

7 he demand for organs for transplantation far outweighs the supply. In 2018, 223 Canadians listed for transplantation died while waiting (Canadian Institute for Health Information, 2019). One solution to addressing this problem is to expand public education and, thereby, increase the number of citizens who enrol to donate their organs after death in provincial registries. In most provinces, citizens need to register their consent for organ donation after death via an electronic registry. In Canada, provincial organ donation organizations obtain family consent prior to proceeding with organ donation, regardless of registration status. If the patient's substitute decision maker is aware that a person has registered consent, they are more likely to offer consent to proceed with organ donation after death (Shah et al., 2018; Siminoff et al., 2001). Fulfilling a person's wish to donate and simultaneously helping a person in need of an organ transplant will benefit all parties involved. Canadian citizens strongly (71\%) or somewhat (25\%) support organ donation after circulatory death (Canadian Council for Donation \& Transplant, 2005), but some provinces have low registration rates, such as British Columbia and Alberta $(20 \%$ and 7\%, respectively, as of 2015; Canadian Blood Services, 2016). 
In Ontario, approximately $35 \%$ of the population is registered (Trillium Gift of Life Network, 2019).

Most Canadian citizens register consent with renewal of their health card or driver's license (Rosenblum et al., 2012) but, given the reality of low registration rates, alternative strategies are clearly necessary. Considering the large volume of patients that visit Canadian emergency departments (EDs), spreading awareness of organ donation registration in the ED may prove to be an important means of expanding donor registries. Since nurses are key stakeholders when it comes to ED operations, it is important to understand their attitudes and sense of acceptability for this novel potential intervention. To date, there is little literature examining the role of primary care and other health-related settings pertaining to organ donation promotion (Jones et al., 2017).

Our primary objective was to explore emergency nurses' attitudes and acceptability of utilizing the ED to promote organ donation registration. In addition, we examined perceived facilitators and barriers and nurses' comfort levels with various provider types initiating a personal approach to discuss organ donation registration with patients in the ED. Secondarily, we assessed nurses' support for deceased organ donation and the proportion who are personally registered for donation.

\section{Methods}

\section{Study design and participants}

This study was a cross-sectional, electronically administered survey of Canadian emergency nurses. The survey was distributed to all 1,270 active members of the National Emergency Nursing Association (NENA). NENA is a nationally recognized association of more than 1,000 registered nurses that promotes the highest standards and practices in emergency nursing and emergency departments in Canada.

\section{Survey development}

The survey was developed using a modified Dillman's tailored design method (Dillman, 2007). In order to develop the survey instrument, we first performed a standardized key informant interview with stakeholders who have expertise in organ donation and clinical research that included critical care and emergency nurses and physicians. This process was overseen by two research methodologists with expertise in survey development. Cognitive interviews with a separate group of $10 \mathrm{critical}$ care nurses were then performed. Here, participants were asked to self-administer the survey on paper under observation and openly express their thoughts, observations and concerns. This allowed for validation and sensibility of the content, language and grammar. After some minor adjustment to the survey, we then translated the survey to French and distributed this pilot draft of the survey to 10 local English and French emergency nurses electronically to identify any potential problems with the procedure or completion of the survey. No changes were required after the pilot phase and therefore these responses were included in the data analysis. A total of 24 questions were included in the final survey under four domains and administered using a five-point Likert scale: demographics and practice information, attitudes toward organ donation, acceptability of
ED organ donation registration, and related perceived facilitators and barriers (Appendix 1). This study was approved by the Ottawa Health Science Network Research Ethics Board.

\section{Survey administration}

The survey was sent via e-mail as a web link to all current members on the NENA distribution list. The initial contact included a brief introduction outlining the justification of the survey, the importance of nurses' input on the topic, and that responding to the survey would imply presumed consent to participate. A reminder email was sent two weeks after the initial request. The survey was available in both English and French languages and was available for completion during the period of December 15, 2019 to February 15, 2020 using SelectSurvey.NET ${ }^{\mathrm{TM}}$ online software (ClassApps, Kansas City, MO, USA). We were unable to determine the characteristics of the non-respondents, as the NENA membership database is confidential.

\section{Data analysis}

Anonymized responses were reported in an automatically generated Microsoft Excel spreadsheet through SelectSurvey.NET ${ }^{\mathrm{TM}}$ and used for analysis. Descriptive statistics were used to summarize nurses' responses. Data were analyzed using SAS version 9.2 (SAS Institute, Cary, NC, USA).

\section{Results}

\section{Respondents}

A total of 1,270 emergency nurses were contacted to participate via the NENA email distribution list. Of these, there were 130 responses from eligible participants, resulting in a response rate of $10.2 \%$. Demographic information for the respondents is presented in Table 1. Characteristics of respondents demonstrate eclectic educational backgrounds, training types and amount of experience. Although this was distributed nationally, the majority of responses were from nurses practicing in Ontario (36.9\%), Alberta (16.9\%) and British Columbia 16.2\%).

\section{Attitudes and Acceptability of ED Organ Donation Registration}

As depicted in Table 2, 104 (80\%) respondents reported that they are registered as organ donors. The most common reported reason for those who are not registered was due to not knowing how to register.

Most respondents either "strongly support" or "somewhat support" the general concept of deceased organ donation (110; $84.6 \%$ and $100 ; 76.9 \%$ ), respectively (Table 3 ). In addition, 80 or $61.5 \%$ of respondents either "strongly support" or "somewhat support" dissemination of information about organ donation to patients the ED waiting area, and 76 (58.4\%) either "strongly support" or "somewhat support" offering ED patients and visitors an immediate opportunity to register while they await medical care. A minority of respondents felt that ED patients would be open to receiving information regarding organ donation in the ED (40; $38.3 \%$; Table 3). Similarly, 47 (36.2\%) felt that ED patients would be open to being offered an immediate opportunity to register as an organ donor in the ED. However, 86 (66.2\%) felt that ED patients would not be open to receiving instructions on how to register as an organ donor after their ED visit is completed. 


\begin{tabular}{|c|c|}
\hline $\begin{array}{l}\text { Table } 1 \\
\text { Distribution of Respondent Characteristics ( } n=\end{array}$ & \\
\hline Characteristic & $\begin{array}{l}\text { Frequency }(\%) \text { of } \\
\text { Respondents }\end{array}$ \\
\hline Female & $107(72.3)$ \\
\hline Mean age, years (SD) & $42.8(8.4)$ \\
\hline $\begin{array}{l}\text { Years in practice } \\
\quad<5 \\
\quad 5-10 \\
\quad 11-20 \\
>20\end{array}$ & $\begin{array}{l}15(11.5) \\
29(22.3) \\
37(28.5) \\
49(37.7)\end{array}$ \\
\hline $\begin{array}{l}\text { Religious Affiliation } \\
\text { Christian } \\
\text { None } \\
\text { Other } \\
\text { Hindu } \\
\text { Jewish } \\
\text { Muslim } \\
\text { Sikh } \\
\end{array}$ & $\begin{array}{c}66(50.8) \\
53(40.8) \\
5(3.8) \\
2(1.5) \\
2(1.5) \\
2(1.5) \\
0 \\
\end{array}$ \\
\hline $\begin{array}{l}\text { Location of practice } \\
\text { Ontario } \\
\text { Alberta } \\
\text { British Columbia } \\
\text { Nova Scotia } \\
\text { Saskatchewan } \\
\text { Manitoba } \\
\text { Quebec } \\
\text { Newfoundland and Labrador } \\
\text { New Brunswick } \\
\text { Northwest Territories } \\
\text { Nunavut } \\
\text { Prince Edward Island } \\
\text { Yukon Territory } \\
\text { Missing }\end{array}$ & $\begin{array}{c}48(36.9) \\
22(16.9) \\
21(16.2) \\
9(6.9) \\
8(6.2) \\
7(5.4) \\
5(3.8) \\
4(3.1) \\
3(2.3) \\
0 \\
0 \\
0 \\
0 \\
3(2.3) \\
\end{array}$ \\
\hline $\begin{array}{l}\text { Practice setting } \\
\text { Academic / Tertiary } \\
\text { Community (Teaching) } \\
\text { Community (Non-teaching) } \\
\text { Rural } \\
\text { Other }\end{array}$ & $\begin{array}{l}63(48.5) \\
45(34.6) \\
19(14.6) \\
1(0.8) \\
2(2.3)\end{array}$ \\
\hline $\begin{array}{l}\text { Professional designation } \\
\text { Registered Nurse (Bachelor of Science } \\
\text { Nursing) } \\
\text { Registered Nurse } \\
\text { Registered Nurse (Bachelor of Nursing) } \\
\text { Other } \\
\text { Nurse Practitioner } \\
\text { Licensed Practical Nurse }\end{array}$ & $\begin{array}{c}63(48.5) \\
34(26.2) \\
23(17.7) \\
8(6.2) \\
1(0.8) \\
1(0.8)\end{array}$ \\
\hline $\begin{array}{l}\text { Highest level of education } \\
\text { Bachelor's degree } \\
\text { College diploma } \\
\text { Master's degree } \\
\text { Hospital training program } \\
\text { Other } \\
\text { Doctorate degree }\end{array}$ & $\begin{array}{c}81(62.3) \\
23(17.7) \\
15(11.5) \\
5(3.8) \\
5(3.8) \\
1(0.8) \\
\end{array}$ \\
\hline $\begin{array}{l}\text { Employed by provincial organ donation } \\
\text { organization } \\
\text { Yes } \\
\text { No } \\
\text { Unanswered }\end{array}$ & $\begin{array}{c}3(2.3) \\
117(90) \\
10(7.7)\end{array}$ \\
\hline
\end{tabular}

Comfort Levels with Active Approach by Provider Type

We found that 108 respondents (83.1\%) were either "very comfortable" or "somewhat comfortable" with provincial organ donation organization personnel performing a personal approach (Table 4). This compares to $77(59.2 \%)$ and $66(50.8 \%)$ that were either "very comfortable" or "somewhat comfortable" with the emergency physician and emergency resident physicians approaching patients about organ donation in the ED, respectively. 83 nurses (63.9\%) were "very comfortable" or "somewhat comfortable" with research staff making the approach. $48.5 \%$ of respondents felt "very comfortable" or "somewhat comfortable" with emergency nurses, and a minority were either "very comfortable" or "somewhat comfortable" with medical students, administrative clerks and hospital volunteers (40 or 30.8\%; 35 or $26.9 \%$; and 27 or $20.8 \%$, respectively), making the approach.

\section{Respondents' Support for Information Delivery Methods} Regarding Organ Donation to ED Patients

One hundred respondents (76.9\%) felt that signage posted in ED waiting areas should be utilized and $97(74.6 \%)$ felt that an active personal approach to offer information would be acceptable. $80(61.5 \%)$ reported that an electronic device (e.g., iPad) would be acceptable.

\section{Perceived Potential Facilitators and Barriers in the Promotion of Organ Donation Registration in the ED}

Most nurses felt that many potential facilitators may play a role in the promotion of organ donation registration in the ED. $91(70.1 \%)$ of respondents felt that the societal/public importance of increasing donation rates was either a "very significant" or "somewhat significant" facilitator. A patient's previous awareness of donation, their personal willingness to help others, and having a strong donation culture at the institution were reported as being "very significant" or "somewhat significant" by 84 respondents (64.6\%), 78 (60\%), and 77 (59.3\%), respectively.

\section{Table 2}

Respondents Personal Donor Registration Status and Reasons for Non-Registration $(N=130)$

\begin{tabular}{|l|c|}
\hline \multicolumn{1}{|c|}{ Registration Status } & \# (\%) of Respondents \\
\hline Registered & $104(80)$ \\
\hline Not registered & $22(16.9)$ \\
\hline Unanswered & $4(3.1)$ \\
\hline Reasons for non-registration & $4(3.1)$ \\
\hline I don't know how to register & $2(1.5)$ \\
\hline I don't have time to register & $2(1.5)$ \\
\hline Religious beliefs & $3(2.3)$ \\
\hline Personal beliefs & $3(2.3)$ \\
\hline $\begin{array}{l}\text { My organs are not suitable due to } \\
\text { medical problems }\end{array}$ & $1(0.8)$ \\
\hline \begin{tabular}{l} 
I prefer not to donate my organs \\
\hline \begin{tabular}{l} 
Other \\
\hline
\end{tabular}
\end{tabular} & $5(3.9)$ \\
\hline
\end{tabular}


Table 3

Attitudes and Acceptability of Organ and Tissue Donation Registration in the Emergency Department (\%, N=130)

\begin{tabular}{|c|c|c|c|c|c|}
\hline Question/Statement & $\begin{array}{l}\text { Strongly } \\
\text { Support }\end{array}$ & $\begin{array}{l}\text { Somewhat } \\
\text { Support }\end{array}$ & Neutral & $\begin{array}{l}\text { Somewhat } \\
\text { Oppose }\end{array}$ & $\begin{array}{l}\text { Strongly } \\
\text { Oppose }\end{array}$ \\
\hline $\begin{array}{l}\text { 1. In general, do you support the concept of deceased organ } \\
\text { donation? }\end{array}$ & 84.6 & 6.9 & 5.4 & 0.8 & 2.3 \\
\hline $\begin{array}{l}\text { 2. Provincial organ donation organizations should attempt to } \\
\text { increase the number of registered organ donors. }\end{array}$ & 76.9 & 15.4 & 6.9 & 0.8 & 0 \\
\hline $\begin{array}{l}\text { 3. The emergency department waiting area is an appropriate } \\
\text { setting to disseminate information regarding organ and tissue } \\
\text { donation to capable patients who do not need immediate atten- } \\
\text { tion and visitors. }\end{array}$ & 22.3 & 39.2 & 23.1 & 12.3 & 3.1 \\
\hline $\begin{array}{l}\text { 4. The emergency department waiting area is an appropriate } \\
\text { setting to offer patients and visitors an immediate opportunity } \\
\text { to register as an organ and tissue donor while they await medical } \\
\text { care. }\end{array}$ & 19.2 & 39.2 & 25.9 & 13.4 & 2.3 \\
\hline $\begin{array}{l}\text { 5. Emergency department patients would be open to receiving } \\
\text { information regarding deceased organ donation in emergency } \\
\text { department waiting areas. }\end{array}$ & 4.6 & 26.2 & 43.5 & 22.3 & 3.4 \\
\hline $\begin{array}{l}\text { 6. Emergency department patients would be open to being } \\
\text { offered an immediate opportunity to register for deceased organ } \\
\text { donation in emergency department waiting areas. }\end{array}$ & 6.2 & 30 & 33.8 & 27.7 & 2.3 \\
\hline $\begin{array}{l}\text { 7. Emergency department patients would be open to being } \\
\text { offered instructions on how to register as an organ donor in the } \\
\text { future, following their emergency department visit. }\end{array}$ & 13.1 & 53.1 & 26.8 & 6.2 & 0.8 \\
\hline
\end{tabular}

Table 4

Nurses' Comfort Levels of Various Provider Types to Actively Approach ED Patients and Visitors (\%, N=128)

\begin{tabular}{|l|c|c|c|c|c|}
\hline \multicolumn{1}{|c|}{ Provider Type } & $\begin{array}{c}\text { Very } \\
\text { Comfortable }\end{array}$ & $\begin{array}{c}\text { Somewhat } \\
\text { Comfortable }\end{array}$ & Don't Know & $\begin{array}{c}\text { Somewhat } \\
\text { Uncomfortable }\end{array}$ & $\begin{array}{c}\text { Very } \\
\text { Uncomfortable }\end{array}$ \\
\hline Emergency physician & 40.0 & 19.2 & 19.3 & 6.9 & 14.6 \\
\hline Emergency resident & 30.8 & 20.0 & 23.0 & 19.2 & 13.1 \\
\hline Medical student & 13.9 & 16.9 & 19.9 & 21.5 & 16.2 \\
\hline Emergency nurse & 22.3 & 26.2 & 23.9 & 3.1 & 27.7 \\
\hline Administrative clerks & 10.0 & 16.9 & 10.7 & 6.9 & 3.1 \\
\hline Provincial ODO* staff & 63.9 & 19.2 & 23.0 & 15.4 & 6.2 \\
\hline Research staff & 40.0 & 23.9 & 27.6 & & 36.2 \\
\hline Hospital volunteer & 10.0 & 10.8 & & & \\
\hline * organ donation organization & & & & \\
\hline
\end{tabular}

Several barriers to the consideration of organ donation registration in ED waiting areas that were considered "very significant" or "somewhat significant" by nurses are listed in Table 5. Logistical barriers such as time constraints 99 (76.2\%) and availability of personnel $(106 ; 81.5 \%)$ were reported most frequently, followed by those related to ethics $(87 ; 66.9 \%)$ and religious barriers $(85 ; 65.4 \%)$.

\section{Discussion}

Our study explored emergency nurses' attitudes and acceptability of potentially utilizing the ED waiting area to disseminate information regarding deceased organ donation and offer patients and visitors an opportunity to become registered organ donors. The vast majority of nurses support the concept of deceased organ donation and 104 nurses $(80.0 \%)$ in our sample 
Figure 1

Support for Information Delivery Methods Regarding Organ Donation to Emergency Department Patients (\%, N=129)

\section{Support for Strategies to Facilitate Organ Donation Registration in the ED (\%)}

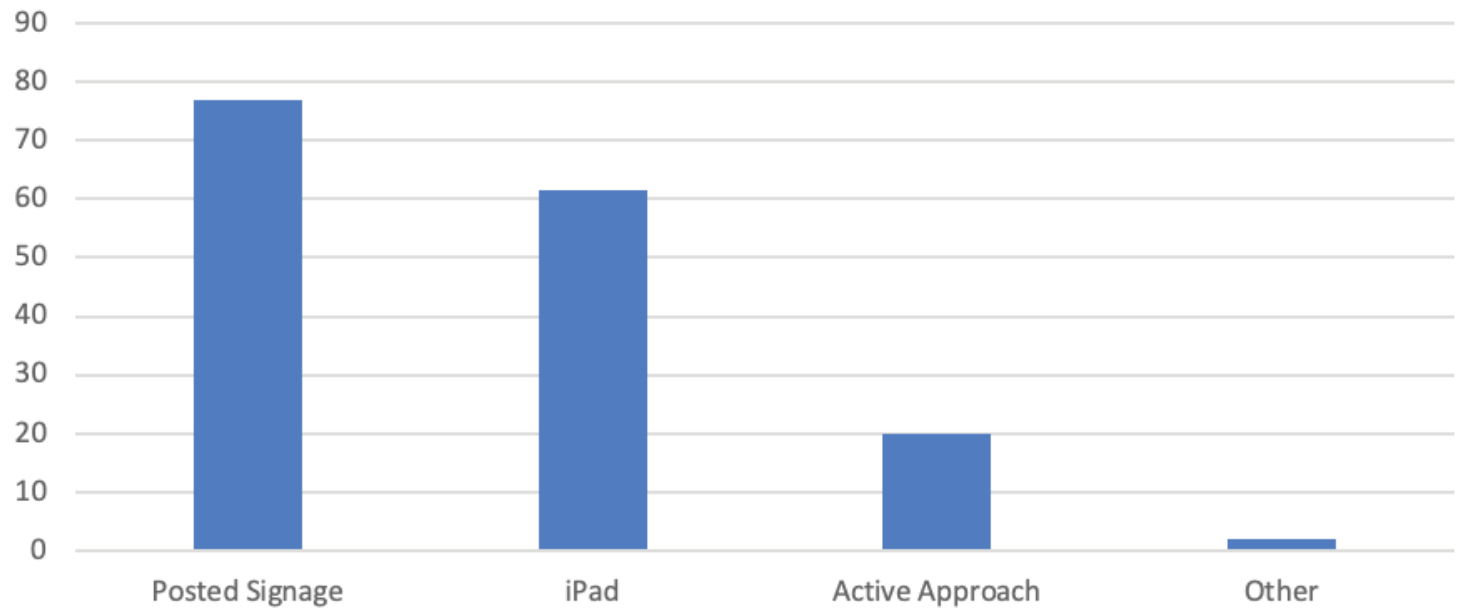

- Support for Strategies to Facilitate Organ Donation Registration in the ED (\%)

Table 5

Perceived Potential Facilitators and Barriers of Organ Donation Registration in the ED (\%, N=127)

\begin{tabular}{|c|c|c|c|c|c|}
\hline Facilitator & $\begin{array}{l}\text { Very } \\
\text { Significant }\end{array}$ & $\begin{array}{l}\text { Somewhat } \\
\text { Significant }\end{array}$ & Don't Know & $\begin{array}{l}\text { Somewhat } \\
\text { Insignificant }\end{array}$ & $\begin{array}{l}\text { Very } \\
\text { Insignificant }\end{array}$ \\
\hline Strong donation culture at institution & 23.9 & 35.4 & 13.9 & 14.6 & 4.6 \\
\hline $\begin{array}{l}\text { Societal/public importance of } \\
\text { increasing donation rates }\end{array}$ & 36.2 & 33.9 & 6.9 & 7.7 & 6.9 \\
\hline Patients' willingness to help others & 30.0 & 30.0 & 17.7 & 8.5 & 5.4 \\
\hline $\begin{array}{l}\text { Patient's previous awareness of } \\
\text { donation }\end{array}$ & 29.2 & 35.4 & 8.5 & 11.5 & 4.6 \\
\hline Barrier & $\begin{array}{l}\text { Very } \\
\text { Significant }\end{array}$ & $\begin{array}{l}\text { Somewhat } \\
\text { Significant }\end{array}$ & Don't Know & $\begin{array}{l}\text { Somewhat } \\
\text { Insignificant }\end{array}$ & $\begin{array}{l}\text { Very } \\
\text { Insignificant }\end{array}$ \\
\hline Ethical barriers & 27.7 & 39.2 & 6.2 & 15.4 & 2.3 \\
\hline Religious barriers & 36.9 & 28.5 & 7.7 & 13.9 & 3.9 \\
\hline Lack of patient interest & 22.3 & 36.9 & 17.7 & 10.8 & 2.3 \\
\hline Time constraints & 47.7 & 28.5 & 5.4 & 6.2 & 3.1 \\
\hline Department flow/efficiency & 51.5 & 25.4 & 3.9 & 5.4 & 3.1 \\
\hline Availability of staffing/personnel & 64.6 & 16.9 & 2.3 & 3.1 & 3.1 \\
\hline Hospital costs & 11.5 & 24.6 & 26.9 & 19.2 & 6.2 \\
\hline Patient privacy & 20.0 & 30.8 & 10.0 & 20.8 & 9.2 \\
\hline $\begin{array}{l}\text { Staff skill/confidence in discussing } \\
\text { organ donation }\end{array}$ & 37.7 & 38.5 & 3.9 & 9.2 & 1.5 \\
\hline
\end{tabular}


are personally registered as organ donors. Most nurses in our study felt that the ED is an acceptable venue to promote organ donation, although the optimal mechanism to do so is less clear. Several facilitators were identified and supported by nurses, such as a patients' and society's support for organ donation in general, and the institutional culture of organ donation. Similarly, several barriers were deemed as significant, mainly centred around time spent, departmental efficiency, and personnel availability. A significant number of nurses also felt that ethical and religious barriers exist.

Some previous literature is consistent with our findings that nurses generally have a positive attitude towards organ donation (Ingram et al., 2002; Ozdag, 2001), but there is little previously published work regarding organ donation registration in the ED. Surprisingly, a majority of nurses felt that patients would not be open to registering consent while in the ED, which is in contrast to previously published literature (Ellis et al., 2019). Ellis et al. reported that the majority of ED patients would be supportive of the distribution of information regarding organ and tissue donation, and that one-third of patients who are not currently registered would consider registering to become a potential organ donor while in the ED waiting room (Ellis et al., 2019). This finding contrasts with what emergency nurses in the current study perceive about patients' open mindedness to ED organ donation registration. It is possible that nurses feel that patients visit the ED only for an acute medical reason and, therefore, would feel distracted by having their attention drawn to something that is unrelated to the ED visit. Nurses may also feel that patients should not be approached to discuss organ donation during a time when they need acute medical care, in order to avoid patients feeling that the care they receive may be impacted by their decision regarding becoming a registered organ donor.

This study has some limitations. The response rate of 130 nurses (10.2\%) means that non-response bias cannot be ruled out and, therefore, our results may not be an accurate representation of the attitudes and opinions of all emergency nurses in Canada. This response rate is in keeping with a previous survey administered to the same distribution list (Hancock et al., 2017), which demonstrated a response rate of $11.4 \%$. Internet-based surveys have been shown to have a significantly lower response rate than postal surveys in healthcare professionals (Cho et al., 2013). However, we were unable to find a mechanism that would enable us to target emergency nurses via post. The potential for selection bias on the sampling frame also exists, given that not all Canadian emergency nurses are registered as NENA members. The baseline characteristics of nurses in our sample are quite diverse, and it is unclear if this sample yields a true representation of emergency nurses in Canada. Due to the confidential nature of the NENA membership database, we were unable to examine characteristics of non-respondents in an attempt to assess for non-response bias. Additionally, it is possible that respondents who are registered donors themselves may be more likely to respond to a survey regarding organ donation.

Future research should aim to compare the results of this study with the attitudes and opinions of other key ED stakeholders to ultimately form the foundation of an implementation strategy that can be piloted in the ED. In addition, it may be of value to further explore nurses' perceptions of patients' willingness to register while in the ED. Furthermore, the barriers we have identified could be further explored using a qualitative approach to inform future implementation.

\section{Conclusion}

This study reveals that Canadian emergency nurses are very engaged and supportive of organ donation and the majority feel that the ED is an appropriate venue to promote organ donation. Public importance of increasing donation rates, the recognition of patients' willingness to help others, and strong institutional donation culture were all identified as facilitators to this important potential intervention in EDs. Some barriers were also identified, such as time constraints and departmental efficiency and flow.

\section{Implications for Emergency Nurses}

1. Emergency nurses largely support the concept of deceased organ donation, and most are registered organ donors.

2. Most emergency nurses are open to the promotion of organ donation registration in the ED.

3. Respondents would be most comfortable with organ donation organization personnel performing a face-to-face approach in speaking about organ donation

4. While respondents report generally supporting a registration intervention in the $\mathrm{ED}$, the ideal mechanism to achieve this is not clear and requires further study.

\section{Funding}

Dr. Jeffrey Perry is supported by the Heart and Stroke Foundation of Ontario through a Mid-Career Award.

Dr. Michael Hartwick receives a salary as Regional Medical Lead Donation from Trillium Gift of Life Network, Ontario's organ donation organization.

Dr. Michael Hickey receives a salary as Hospital Donation Physician from Trillium Gift of Life Network, Ontario's organ donation organization.

This study was partially funded by a grant from the Department of Emergency Medicine, University of Ottawa.

\section{About the Authors}

Michael Hickey, MD, MSc, Department of Emergency Medicine, University of Ottawa, Ottawa, Ontario

Dr. Hickey is an Assistant Professor at the University of Toronto. He attended medical school at Memorial University of Newfoundland and is board certified in both emergency and critical care medicine from the University of Ottawa. He has completed a clinical fellowship in organ donation science through Trillium Gift of Life Network in Ontario and a Master of Science in Epidemiology. He currently practices emergency and critical care medicine in Toronto.

Carly Hickey, MN, is a registered nurse with extensive experience in critical care nursing at a level 1 trauma centre. She has also worked as a clinical educator in both critical care and general internal medicine. She has a Master of Nursing from Athabasca University 
and has research interests in organ donation, patient advocacy and family involvement in critical care.

Michael Hartwick, MD, MEd, Associate Professor, Department of Medicine, Divisions of Critical Care and Palliative Medicine, University of Ottawa, Ottawa, Canada

Lauralyn McIntyre, MD, MSc, Clinical Epidemiology Program, Ottawa Hospital Research Institute, Ottawa, Ontario; Division of Critical Care, Department of Medicine, University of Ottawa, Ottawa, Ontario

Monica Taljaard, Senior Scientist, Clinical Epidemiology Program, Ottawa Hospital Research Institute, Ottawa, Canada and Professor, School of Epidemiology and Public Health, University of Ottawa, Ottawa, Ontario

Krishan Yadav, MD, MSc, Department of Emergency Medicine, University of Ottawa, Ottawa, Ontario

Aimee J. Sarti, MD, MMEd, Clinical Epidemiology Program, Ottawa Hospital Research Institute, Ottawa, Ontario; Division of Critical Care, Department of Medicine, University of Ottawa, Ottawa, Ontario
Jeffrey J. Perry, MD, MSc, Department of Emergency Medicine, University of Ottawa, Ottawa, Ontario; Clinical Epidemiology Program, Ottawa Hospital Research Institute, Ottawa, Ontario

Dr. Perry is a Professor with the Department of Emergency Medicine, University of Ottawa, and a Senior Scientist with the Ottawa Hospital Research Institute. He completed the family medicine residency program at the Memorial University of Newfoundland and emergency medicine residency at the University of Manitoba and subsequently completed the Emergency Medicine Research Fellowship at the University of Ottawa, and obtained a Master of Science in Epidemiology in 2002. He holds a Research Chair in Emergency Neurological Research from the University of Ottawa. He previously held a Canadian Institutes for Health Research New Investigator Award and an Ontario Ministry of Health Career Scientist Award.

\section{Corresponding Author: Michael Hickey}

Email:michael.hickey@unityhealth.to

Address: St. Joseph's Health Centre, 30 The Queensway, Toronto, Ontario M6R $1 B 5$

\section{REFERENCES}

Canadian Blood Services. (2016). Organ donation and transplantation in Canada: System progress report 2006-2015. https://www.blood. $\mathrm{ca} /$ sites/default/files/ODT_Report.pdf

Canadian Council for Donation and Transplantation. (2005). Public awareness and attitudes on organ and tissue donation and transplantation including donation after cardiac death. https:// profedu.blood.ca/sites/msi/files/Public_Survey_Final_Report.pdf

Canadian Institute for Health Information. (2019). Annual statistics on organ replacement in Canada: Dialysis, transplantation and donation, 2009 to 2018. https://www.cihi.ca/sites/default/ files/document/corr-dialysis-transplantation-donation-20102019-snapshot-en.pdf https://www.cihi.ca/sites/default/files/ document/corr-snapshot-2019-en.pdf

Cho, Y. I., Johnson, T. P., \& Vangeest, J. B. (2013). Enhancing surveys of health care professionals: A meta-analysis of techniques to improve response. Eval Health Prof, 36(3), 382-407. https://doi. org/10.1177/0163278713496425

Dillman, D. A. (2007). Mail and internet surveys: The tailored design method (2nd ed.). Wiley.

Ellis, B., Hartwick, M., \& Perry, J.J. (2019). Register to donate while you wait: Assessing public opinions of the acceptability of utilizing the emergency department waiting room for organ and tissue donor registration. CJEM, 21(5), 622-625. https://doi.org/10.1017/ cem.2019.347

Hancock, J., Shemie, S. D., Lotherington, K., Appleby, A., \& Hall, R. (2017). Development of a Canadian deceased donation education program for health professionals: A needs assessment survey. Can J Anaesth, 64(10), 1037-1047. https://doi.org/10.1007/ s12630-017-0882-4

Ingram, J. E., Buckner, E. B., \& Rayburn, A. B. (2002). Critical care nurses' attitudes and knowledge related to organ donation. Dimens Crit Care Nurs, 21(6), 249-255. https://doi. org/10.1097/00003465-200211000-00008

Jones, C. P., Papadopoulos, C., \& Randhawa, G. (2017). Primary care interventions to encourage organ donation registration: A systematic review. Transplant Rev (Orlando), 31(4), 268-275. https://doi.org/10.1016/j.trre.2017.08.006

Ozdag, N. (2001). The nurses' knowledge, awareness and acceptance of tissue-organ donation. EDTNA ERCA J, 27(4), 201-206. https:// doi.org/10.1111/j.1755-6686.2001.tb00179.x

Rosenblum, A. M., Li, A. H., Roels, L., Stewart, B., Prakash, V., Beitel, J., Young, K., Shemie, S. Nickerson, P. \& Garg, A. X. (2012). Worldwide variability in deceased organ donation registries. Transpl Int, 25(8), 801-811. https://doi. org/10.1111/j.1432-2277.2012.01472.x

Shah, M. B., Vilchez, V., Goble, A., Daily, M. F., Berger, J. C., Gedaly, R., \& DuBay, D. A. (2018). Socioeconomic factors as predictors of organ donation.J Surg Res, 221, 88-94. https://doi.org/10.1016/j. jss.2017.08.020

Siminoff, L. A., Gordon, N., Hewlett, J., \& Arnold, R. M. (2001). Factors influencing families' consent for donation of solid organs for transplantation. JAMA, 286(1), 71-77.

Trillium Gift of Life Network. (2019). Registration statistics. https:// beadonor.ca/scoreboard 


\section{Appendix 1: Survey instrument}

\section{EMERGENCY NURSE ATTITUDES AND ACCEPTABILITY OF ORGAN AND TISSUE DONATION REGISTRATION IN THE EMERGENCY DEPARTMENT: A NATIONAL SURVEY}

A. Professional Status and Practice Setting
1. Are you:
$\square$ Female $\square$ Male

2. Year of birth: 19

Province of Practice:

3. How many years have you been practicing nursing independently?

- Less than 5 years

- Between 5 and 10 years

- Between 10 and 20 years

- Greater than 20 years

4. To which religion do you most identify?

$\square$ Christian $\square$ Buddhist $\square$ Hindu $\square$ Muslim $\square$ Jewish $\square$ Sikh $\square$ Aboriginal $\square$ Other (specify):

$\square$ None

5. In what setting do you perform MOST of your emergency nursing clinical activity?

- Teaching hospital

- Community / District general hospital: Teaching

- Community / District general hospital: Non-teaching

- Other (specify):

6. What is your current qualification?

- RN

- LPN

- $\mathrm{BN}$

- RPN

- $\mathrm{BScN}$

- NP

- MN (non-NP)

- Other (Specify):

7. Do you hold an official affiliation with a provincial organ donation organization?

- Yes

- No

\section{B. Attitudes and Acceptability}

1. Are you personally registered as an organ and tissue donor?

- Yes

- No

2. If no, what is the reason?

- I don't know how to register

- I don't have time to register

- I was not aware that it is possible to register as an organ donor

- Religious beliefs

- Personal beliefs

- Assumed non-suitability of organs due to medical problems

- I prefer not to donate my organs

- Other (specify):

3. In general, do you support the concept of deceased organ donation? 
- Strongly support

- Somewhat support

- Neutral

- Somewhat oppose

- Strongly oppose

4. Provincial organ donation organizations should attempt to increase the number of registered organ donors:

- Strongly agree $\bullet$ Somewhat agree $\bullet$ Neither agree nor disagree $\bullet$ Somewhat disagree $\bullet$ Strongly disagree

5. The emergency department waiting area is an appropriate setting to disseminate information regarding organ and tissue donation to capable patients who do not need immediate attention and visitors:

- Strongly agree $\bullet$ Somewhat agree $\bullet$ Neither agree nor disagree $\bullet$ Somewhat disagree $\bullet$ Strongly disagree

6. The emergency department waiting area is an appropriate setting to offer patients and visitors opportunity to register as an organ and tissue donor while they await medical care:

- Strongly agree $\bullet$ Somewhat agree $\bullet$ Neither agree nor disagree $\bullet$ Somewhat disagree $\bullet$ Strongly disagree

7. Emergency department patients would be open to receiving information regarding deceased organ donation in ED waiting areas:

- Strongly agree $\bullet$ Somewhat agree $\bullet$ Neither agree nor disagree $\bullet$ Somewhat disagree $\bullet$ Strongly disagree

8. Emergency department patients would be open to being offered an immediate opportunity to register for deceased organ donation in ED waiting areas:

- Strongly agree $\bullet$ Somewhat agree $\bullet$ Neither agree nor disagree $\bullet$ Somewhat disagree $\bullet$ Strongly disagree

9. Emergency department patients would be open to being offered instructions on how to register as an organ donor in the future, following their ED visit:

- Strongly agree $\bullet$ Somewhat agree $\bullet$ Neither agree nor disagree $\bullet$ Somewhat disagree $\bullet$ Strongly disagree

10. If emergency department patients have an immediate opportunity to register as an organ donor, this should be facilitated by: (check all that are appropriate)

- Publicly posted signage with instructions

- Electronic devices available in waiting areas (iPad)

- Active approach by personnel

- Other:

11. There may be a number of individuals in the ED who may potentially approach patients and visitors regarding organ donation registration while they await medical care. As a nurse in your ED, please describe your comfort level with the following categories of personnel should they facilitate the approach:

\begin{tabular}{|c|c|c|c|c|c|c|}
\hline & & $\begin{array}{c}\text { Very } \\
\text { uncomfortable }\end{array}$ & $\begin{array}{c}\text { Somewhat } \\
\text { uncomfortable }\end{array}$ & $\begin{array}{c}\text { Don't } \\
\text { know/Unsure }\end{array}$ & $\begin{array}{l}\text { Somewhat } \\
\text { comfortable }\end{array}$ & $\begin{array}{c}\text { Very } \\
\text { comfortable }\end{array}$ \\
\hline a. & $\begin{array}{l}\text { ED } \\
\text { physician/resident }\end{array}$ & $\bullet$ & $\bullet$ & $\bullet$ & - & • \\
\hline b. & Medical student & $\bullet$ & - & - & - & - \\
\hline c. & ED nurse & - & $\bullet$ & - & - & • \\
\hline d. & $\begin{array}{l}\text { ED } \\
\text { administrative } \\
\text { clerks }\end{array}$ & • & • & • & - & • \\
\hline e. & $\begin{array}{l}\text { Provincial organ } \\
\text { donation } \\
\text { organization staff }\end{array}$ & $\bullet$ & $\bullet$ & $\bullet$ & - & $\bullet$ \\
\hline f. & $\begin{array}{l}\text { Hospital } \\
\text { volunteer }\end{array}$ & • & • & • & • & $\bullet$ \\
\hline
\end{tabular}


12. The following are potential facilitators to offering information regarding registration for organ donation in emergency department waiting areas. Please choose an option for each potential facilitator which you feel most appropriately describes the level of significance of the facilitator:

\begin{tabular}{|c|c|c|c|c|c|c|}
\hline & & $\begin{array}{l}\text { Insignificant } \\
\text { facilitator }\end{array}$ & $\begin{array}{c}\text { Somewhat } \\
\text { insignificant } \\
\text { facilitator }\end{array}$ & $\begin{array}{c}\text { Don't } \\
\text { know/Unsure }\end{array}$ & $\begin{array}{l}\text { Somewhat } \\
\text { significant } \\
\text { facilitator }\end{array}$ & $\begin{array}{l}\text { Very } \\
\text { significant } \\
\text { facilitator }\end{array}$ \\
\hline a. & $\begin{array}{l}\text { Strong } \\
\text { donation } \\
\text { culture at } \\
\text { institution }\end{array}$ & $\bullet$ & $\bullet$ & $\bullet$ & $\bullet$ & $\bullet$ \\
\hline b. & $\begin{array}{l}\text { Societal/public } \\
\text { importance of } \\
\text { increasing } \\
\text { organ donation } \\
\text { rates }\end{array}$ & $\bullet$ & $\bullet$ & $\bullet$ & $\bullet$ & $\bullet$ \\
\hline c. & $\begin{array}{l}\text { Patients' } \\
\text { willingness to } \\
\text { help others }\end{array}$ & $\bullet$ & $\bullet$ & $\bullet$ & $\bullet$ & • \\
\hline d. & $\begin{array}{l}\text { Patients' } \\
\text { previous } \\
\text { awareness of } \\
\text { organ donation }\end{array}$ & $\bullet$ & • & $\bullet$ & • & • \\
\hline
\end{tabular}

Please indicate any other facilitators not mentioned above:

13. The following are potential barriers to offering information regarding registration for organ donation in emergency department waiting areas. Please choose an option for each potential barrier which you feel most appropriately describes the level of significance of the barrier:

\begin{tabular}{|c|c|c|c|c|c|}
\hline & & Insignificant barrier & $\begin{array}{c}\text { Somewhat significant } \\
\text { barrier }\end{array}$ & $\begin{array}{c}\text { Very significant } \\
\text { barrier }\end{array}$ & Don't know \\
\hline e. & $\begin{array}{l}\text { Staff or patient } \\
\text { ethical barriers }\end{array}$ & $\bullet$ & $\bullet$ & $\bullet$ & $\bullet$ \\
\hline f. & $\begin{array}{l}\text { Staff or patient } \\
\text { religious } \\
\text { barriers }\end{array}$ & • & • & - & • \\
\hline g. & $\begin{array}{l}\text { Lack of patient } \\
\text { interest }\end{array}$ & • & • & $\bullet$ & $\bullet$ \\
\hline h. & $\begin{array}{l}\text { Time } \\
\text { constraints }\end{array}$ & - & $\bullet$ & $\bullet$ & $\bullet$ \\
\hline i. & $\begin{array}{l}\text { Department } \\
\text { flow/efficiency }\end{array}$ & • & • & $\bullet$ & $\bullet$ \\
\hline j. & $\begin{array}{l}\text { Availability of } \\
\text { staffing / } \\
\text { personnel }\end{array}$ & - & $\bullet$ & • & $\bullet$ \\
\hline k. & Hospital costs & $\bullet$ & $\bullet$ & - & $\bullet$ \\
\hline l. & $\begin{array}{l}\text { Patients' } \\
\text { privacy }\end{array}$ & • & $\bullet$ & - & $\bullet$ \\
\hline m. & $\begin{array}{l}\text { Staff confidence } \\
\text { in ability to } \\
\text { discuss organ } \\
\text { donation }\end{array}$ & • & • & $\bullet$ & $\bullet$ \\
\hline
\end{tabular}

Please indicate any other barriers not mentioned above:

Additional comments regarding this topic or questionnaire: 